\title{
INVESTIGATING INCOME SMOOTHING: EMPIRICAL EVIDENCE FROM SERBIAN'S HOTEL COMPANIES
}

\author{
Dragana Bešlić Obradović ${ }^{1}$ \\ Ivana Bešlić Rupić ${ }^{\mathbb{D}}$ \\ Bojan Rupić ${ }^{3}$
}

DOI: https://doi.org/10.31410/tmt.2020.347

\begin{abstract}
The flexibility in accounting standards and principles, lead to incentives for managers to show a good picture of the companies. It is logical and rational for managers to attempt to smooth income by using certain accounting devices to reduce the companies' income fluctuation over time to improve relations with creditors, investors, and employees. Income smoothing enables companies to stabilize earnings and thereby increase earnings predictability. For detecting income smoothing through examining the financial statements Eckel's (1981) approach (income variability approach) has been the most popular and most used one. In this research study, we use a selection criterion between smoothers and non-smoothers hotel companies based on the income smoothing.
\end{abstract}

This study aims to classify Serbian hotel companies during the period 2016-2019 as smoothing and non-smoothing hotel companies. The method used to determine the presence or absence of income smoothing and the company value results is based on the coefficient of variation model proposed by Eckel (1981). According to the coefficient of variation method, the more the income smoothing (IS) index tends to zero, the more smoothed out the company's earnings are. This study examines the presence of artificial income smoothing in 22 Serbian hotel companies. A binomial test is used to test the hypothesis. As a result of research, there are no significant statistical indicators of income smoothing practices in Serbian hotel companies during the period 2016-2019.

Keywords: Income smoothing, Eckel model, Hotel company, Serbia, Binomial test.

\section{INTRODUCTION}

A ccounting as an information system aims to provide users with useful information that is disseminated throughout the financial statement to rationalize different decisions. The management of a company is obliged to provide financial information for users of financial statements. Looking at the financial statements, the users could, then, assess the performance of its managers and the company. The information on earnings in financial statements is very useful for management to make a decision. However, the existence of profit information encourages management to perform dysfunctional behavior. Maximizing profits by utilizing the flexibility of accounting standards used by companies is one form of dysfunctional behavior. This dysfunctional behavior arises due to the existence of asymmetrical information between the parties concerned. As a result, companies need to involve with earnings management. One of the ways to do this is by engaging with income smoothing practices. Income smoothing is a dimension of the accounts manipulation theme that has been attracting great attention in the accounting literature. A goal of manipulation widely ascribed to managers is the desire to smooth (Savitri, 2019).

Alfa BK University, 3 Palmira Toljatija, 11070 Belgrade, Serbia

2 Alfa BK University, 3 Palmira Toljatija, 11070 Belgrade, Serbia

3 Kapital revizija doo, 1 Vojvode Mišića, 21000 Novi Sad, Serbia 
The concept of income smoothing is connected with the theory of agency (Altaie, Hammood, $\&$ Hassnain, 2017). The theory of the agency emerged as a result of the large size of companies and the separation of ownership from management as an initiative to solve the problem of conflict within the relevant parties of an economic unit. Based on agency theory, the concept of income smoothing states that the practice of income smoothing is influenced by the conflict of interest between managers (agent) and the owner (principal) when each party seeks to achieve or maintain the desired level of prosperity for their interest. The management of companies exploited the accounting principles and standards to achieve their motives by increasing the performance of the company. Accounting standards allow companies to choose methods that facilitate income smoothing practices by managers. Income smoothing has an obvious goal and that is creating a steady growth flow in profit. The existence of agency theory will encourage managers to increase the company's profits. If the profit earned increases, the amount of income tax will also increase. As agents in theoretical agencies, managers will try to minimize taxes to avoid the reduction of manager's performance compensation. It shows that the company continues to pay taxes to the state with an increasing amount, but not significantly to avoid tax audits.

Obaidat (2017) asserted that accounting earnings are of major concern for shareholders as they reflect companies' performance. But due to the flexibility of accounting standards represented by the different treatment alternatives (e.g. depreciation methods) allowed by accounting standards (e.g. International Financial Reporting Standards - IFRS) income has been subject to management influence to smooth it. Income smoothing refers to the use of accounting techniques to level out net income fluctuations from one period to the next. Thus, the research problem led to the following questions:

1. Do Serbian's hotel companies implement income smoothing in the financial statements?

2. There are significant or no significant statistical indicators of income smoothing practices in Serbian hotel companies?

This research study is organized into thematic sections. After the introduction, the second and the third section present a brief description of income smoothing and a review of the papers on this issue. The fourth section describes Eckel (1981) model to measure income smoothing practices. The fifth section contains the results of the empirical analysis. Finally, the sixth and seventh sections summarize the main findings for the Serbian market and future research directions.

\section{RESEARCH OBJECTIVES}

Income smoothing defines as the use of managerial discretion to dampen fluctuations in earnings streams. The more a company employs income smoothing, i.e., uses accruals to reduce the variability of profits, the less possibility there is for the timely acknowledgment of future economic losses, i.e., bad economic news in profits. Income smoothing is one of the incentive accountings that involves adjusting and manipulating fluctuations about some heights of earnings for the business. Income smoothing is a form of earnings management and is defined as the dampening of fluctuations in reported earnings over time. Management is inclined to take actions to increase earnings when earnings are relatively low and to decrease earnings when earnings are relatively high (Al Baaj et al., 2018). Income smoothing is a technique of earnings management is one of the approaches in creative accounting whereby companies make adjustments and manipulate a company's revenue (Firnanti, 2019). Income smoothing represents managers' attempts to use their reporting discretion to intentionally dampen the fluctuations of their companies' earnings realizations. That as long as managers have discretion over accounting choices, they smooth 
reported income and the rate of income growth. On one hand, income smoothing improves earnings informativeness if managers use their discretion to communicate their assessment of future earnings, and, on the other hand, income smoothing makes earnings noisier if managers intentionally distort the earnings numbers. Managers may smooth reported income to meet the bonus target or to protect their job. (Tucker, \& Zarowin, 2006). High ability managers can use smoothing as a channel to reduce information asymmetry. While low ability managers might also smooth earnings, given the skills required to smooth and the potential costs associated with poor smoothing decisions (e.g., financial misstatements, diminished reputation, job loss), that low ability managers are less likely to smooth (Baik, Sunhwa, \& Farber, 2019).

Income smoothing is practiced in accounting to reduce the variability of the accounting results. However, executive discretion is not used only in earnings management. The discretionary power of executives is also reflected in the degree of conservatism of companies. Companies can be more or less conservative in their accounting policies, and that degree of conservatism affects their accounting results. That conservatism can impair the measurement of economic reality by imposing the smallest value between two available alternatives. Financial adjustments that depreciate assets are most often reflected in companies' accounting results, for example, via provisions for loan losses, adjustments to asset depreciation rates, or losses raised by impairment tests. These accounting choices are subjective and are directly related to the degree of discretion of those who draft the financial statements (de Almeida et al., 2012). Income smoothing is the voluntary management of the results to reduce the variability of accounting income (Ergin, 2011). It is accomplished by deferring earnings during the profitable years for use during the downturn years. This process is considered ethical unless it is a fraudulent or abusive activity. Income variability may be changed by shifting losses or expenses from time to time. For example, a business can reduce discretionary costs in the current financial year to advance current time earning which will result in the coming year that the discretionary cost will be expanded. Income smoothing is defined as the deliberate normalization of income to reach the desired trend. Stable income patterns and reduced earnings variability are consistently related to earnings predictability. Income smoothing is one of the earnings management methods by reducing fluctuations in earnings to make it look stable because relatively stable earnings are preferred by investors. Income smoothing can influence investor decisions and have consequences for the capital market.

Baik, Sunhwa, and Farber (2019) suggest that managers believe that smoothing makes their companies' earnings more useful. Financial executives believe that smooth earnings help analysts and investors to predict future earnings. Bora and Saha (2015) examined whether income smoothing garbles earnings information or improves the informativeness of past and current earnings about future earnings and cash-flows. The result revealed that the change in the current stock price of higher-smoothing companies contains more information about their future earnings than does the change in the stock-price of lower-smoothing companies. Smoothing may occur through the accounting processes of recognition, measurement, and disclosure, as well as intentionally. Artificial income smoothing implies the use of accruals, which does not affect cash flow and is not based on economic events; rather, it is similar to a postponement or anticipation of revenues and expenditures. Conversely, real income smoothing involves economic events, such as the sale or purchase of fixed assets, which also affects cash flow. However, in both cases, executives act intentionally to smooth results.

Income smoothing or earning management can be classified into real discretion and technical accounting policy (Al Baaj et al., 2018). In real discretion, the management achieves the target- 
ed number of figures by changing transactions between the firm and stakeholders. Technical accounting policy allows the management to change the accounting estimates or accounting policies. The term earnings management is broader than this practice alone, as it involves many different manipulation techniques, aside from smoothing, which are used to reduce variability in results or to make it grow gradually. If a business has more income smoothing there is less variability of incomes concerning the cash flows and more negative or reduced correlation among expenses and cash flows. Various methods can be carried out by managers as income smoothing actions. Eckel (1981) explained two types of income smoothing: 1. Naturally smoothing (of accounting processes) - natural smoothing results from the income-generating process that produces smooth income, which is not considered a manipulation by the management; 2 . Intentionally smoothing by managers - intentional smoothing can be (Martinez, \& Castro, 2011):

1. Real income smoothing (manipulating and changing transactions) - that named the transactional or economic smoothing. Real smoothing involves making production and investment decisions that reduce income variability. Real income smoothing is the smoothing of profits that occurs when managers take action to compile economic events resulting in a flat income stream (Suyono, 2018);

2. Artificial income smoothing or accounting smoothing (changing the timing of the transaction record) - is the smoothing of profits that occurs when managers manipulate the financial data during accounting records to produce a stable profit stream. Artificial income smoothing is achieved through accounting practices. This type of income smoothing does not include the use of an economic event and transfers revenues and expenses from one period to another period (Thu, \& Khuong, 2017).

The objectives of this research study are:

1. To present and discuss the concepts of income smoothing;

2. To investigate artificial income smoothing in Serbian hotel companies during the period 2016-2019;

3. To measure the practices of income smoothing in the financial statements of hotel companies in the Republic of Serbia.

Eckel's (1981) model is used to satisfy our research objectives. The statistical package for social sciences (Statistical Package for Social Sciences - SPSS) was used to achieve the objectives of this study.

\section{LITERATURE REVIEW}

Scholars and researchers worldwide have dedicated considerable efforts to defining income smoothing. Many studies in the international literature indicate that companies engage in practices to reduce the variance of earnings. Income smoothing can be defined as the increase or decrease of the current earnings in the financial statement by a manager to achieve his own specific goals (Al-Othman, 2019). Income smoothing is a form of earnings management and is defined as the dampening of fluctuations in reported earnings over time. In other words, management is inclined to take actions to increase earnings when earnings are relatively low and to decrease earnings when earnings are relatively high (Fengju et al., 2013). Income smoothing is practiced in accounting to reduce the variability of the accounting results. However, executive discretion is not used only in earnings management (Feres de Almeida et al., 2012).

The management of companies prefers to report a smooth stream of earnings because fluctuations in the profitability of the company are considered to have a negative effect on the com- 
pany's risk profile. Although this misleading of users of the financial statements at first appear to have a negative effect, positive effects of this type of earnings management exist (Thu, \& Khuong, 2017). Kusuma (2005) stands out that managers know that investors prefer smoothed income numbers for several reasons: 1 . smoothed income numbers reduce the estimate of various claimants of the company about the volatility of its underlying earnings process and thereby reduce the assessment of the probability of bankruptcy, 2 . income smoothing reflects the accuracy of the manager's knowledge of the company's future performance, 3 . investors hate shocks because shocks in earnings forecasts increased investors' risk. The purpose of income smoothing is as follows (Alexandri, \& Anjani, 2014):

1. Improving: the company's image in the eyes of outsiders that the company has a low risk; the business relationship satisfaction; the perception of external parties on the ability of management;

2. Providing relevant information to make predictions against earnings in the future;

3. Increasing compensation for management;

4. Minimizing taxes, particularly in cases where the company has a large tax debt.

\section{MEASURING INCOME SMOOTHING: ECKEL (1981) MODEL}

Taking into account the accounting scandals concerning Enron, WorldCom, and Parmalat, previous research studies worldwide have been interested in investigating income smoothing existence, its objectives, types (real or artificial), objects (e.g. gross profit, net income), factors leading to income smoothing, tools, motivations, and their effect on companies and stakeholders. One of the most popular models and the most referred to by many researchers to detect the smoothing of accounting income are (Mushtaq, Sultan, \& Ijaz, 2016; Altaie, Hammood, \& Talab, 2017): 1. model by Copeland and Licastro, 2. model by Imhoff, 3. model by Eckel, 4 . Jones model, 5. Levitt model and 6. Mulford and Comiskey model. The study results Thu and Khuong (2017) suggest that the Eckel index is suitable for the Vietnam stock market and shows a slight increase compared to the previous research. Also, Al Baaj et al. (2018) proposes that to determine the income smoothing the coefficient of variation by Eckel's is best to be applied.

The Eckel's (1981) model proposes that to show the connection between net income and sales, the coefficient of variation in net income and sales should be used. The model is based on the premise that revenues and costs are linear over a period hence they are directly related. Therefore, they grow or decline at the same rate; when a linear relationship is not observed, this property may be due to interference from executives to smooth the results. Eckel model use is there for identifying smoothing companies from non-smoothing. The model developed by Eckel (1981) examined the smoothing of income based on the comparison between net incomes' change and sales' change. The income variability approach is selected by Eckel to examine artificial income smoothing. Eckel method looks more at identifying the artificial one as it distorts the appearance of the economic reality. According to Eckel (1981) model, a company is regarded as smoother if its ratio of dispersion coefficient during a period of net income (gross, operational, or net profit) to dispersion coefficient during a sales period is less than one (1) (Nejad, Zeynali, $\&$ Alav, 2013). The income smoothing (IS) index has calculated the measure of smoothing as an index of the fraction between the coefficients of variation - CV. Income smoothing is estimated using Eckel's index (EI) formula (Fengju et al., 2013; Husaini, \& Sayunita, 2016):

$$
\text { Eckel's index (EI) or Income smoothing (IS) index }=C V_{\Delta \% \text { Net income }} / C V_{\Delta \% \text { Sales }}
$$


Where:

$\mathrm{IS}_{\mathrm{i}}$ - The income smoothing index for company $i$;

$\Delta \%$ Net income - Annual change in net income (the change in net income for one term);

$\Delta \%$ Sales - Annual change in sales revenue (the change in sales for one term).

The Eckel (1981) model relates the coefficient of variation in net income to sales. According to de Almeida et al. (2012), an interval between 0.9 and 1.1 is considered a gray area in which it is not possible to sort companies into smoothers or non-smoothers. This procedure allows for the objective classification of companies, thus reducing the risk of bias from the researcher. The following formula defines the gray area:

$$
0.9 \leq\left|C V_{\Delta \% \text { Net income }} / C V_{\Delta \% \text { Sales }}\right|<1.1
$$

This shows that if the Eckel's index (EI) or Income smoothing (IS) index obtained is less than 0.9, the company performs income smoothing, and if the Eckel's index (EI) or Income smoothing (IS) index is greater than 1.1, the company does not perform income smoothing.

The coefficients of variation of net income and sales are calculated as follows (Kusuma, 2005):

$$
\begin{aligned}
& C V_{\Delta \mathrm{I}}=\sigma_{I \mid} \mu_{I \mid} \\
& C V_{\Delta \mathrm{S}}=\sigma_{S} \mu_{S}
\end{aligned}
$$

Where:

$\mathrm{CV}_{\Delta I}$ - The coefficient of variation of net income change for the company $i$ in the period range of study (ratio of the standard deviation to the mean);

$\mathrm{CV}_{\Delta S}$ - The coefficient of variation of sales change for the company $i$ in the period range of study;

$\sigma_{\mathrm{S}}, \sigma_{\mathrm{I}}-$ The standard deviations of sales and net income series for the company $i$ (ratio of the standard deviation to the mean);

$\mu_{\mathrm{S}},\left|\mu_{\mathrm{I}}\right|$ - The means of sales and the absolute value of the means of net income series for the company $i$;

| ... | - Absolute value.

To observe the relationship between net income and sales, the coefficients of the percentage variations of net income and sales are used. When the coefficient of the net income is less than that of the sales, this demonstrates that the company is interfering in the profits through artificial smoothing. Based on this, it is assumed that an index lower than one $(<1)$ in absolute value indicates the presence of income smoothing because the coefficient of variation of net income - $\mathrm{CV}_{\Delta \% \text { Net income }}$ is smaller than the coefficient of variation of sales $-\mathrm{CV}_{\Delta \% \text { Sales }}$ (Altaie, Hammood, \& Talab, 2017):

$$
I S=C V_{\Delta \% \text { Net income }}<C V_{\Delta \% \text { Sales }} \Rightarrow \text { Income smoothing }
$$

When:

Income smoothing (IS) index $<1$, the company has income smoothed its interests (the company is an artificial income smoother);

Income smoothing (IS) index $>1$, the company hasn't income smoothed its interests. 
This ratio calculates the absolute value for the coefficient of variation (which is defined as the ratio of the standard deviation to the mean) of the net income divided by the absolute value for the coefficient of variation of sales. If sales have more variation than net income, the company is said to be artificially smooth (Abdullah Al Baaj, Hadi Al-Zabari, \& Shareef Al Marshedi, 2018). In brief, the companies with absolute value are equal to $(=)$ or smaller $(<)$ than one $(1)$ income smoothing (IS) index is categorized as a company that does the practice of income smoothing (the company is identified as a smoother). On the contrary, the company with income smoothing (IS) index are greater $(>)$ than one (1) are not considered the practice of income smoothing (the company is identified as a non-smoother) (Namazi, \& Khansalar, 2011; Kustonovo, 2011; Fengju et al., 2013).

\section{METHODOLOGY OF RESEARCH AND HYPOTHESIS}

In this research study, the Eckel (1981) model was used for identifying income smoothing. The Eckel's model was used to classify hotel companies in Serbia as smoothing or non-smoothing. The study on income smoothing of hotel companies in Serbia will be performed by SPSS (Statistical Package for Social Sciences) IBM SPSS Statistics Version 20.0. In this study, the following statistical methods were used:

1. Descriptive statistics: includes a set of statistics aimed to introduce the variables of the study, including means, standard deviations, minimum and maximum;

2. Binomial test: is a non-parametric statistical procedure for determining whether the frequency distribution of nominal scaled, dichotomous variables corresponds with an assumed distribution. Here, the probability of the respective variable assuming one of the two characteristics is compared with the actual frequency. The observations classify into one of two mutually exclusive categories: 1- if the company smooths income or 0 - if the company does not smooth. A binomial test is run to see if observed test results differ from what was expected. Assumptions for the binomial test (Martinez, \& Castro, 2011): 1. items are dichotomous (i.e. there are two of them) and nominal, 2. the sample size is significantly less than the population size, 3. the sample is a fair representation of the population and 4. sample items are independent (one item has no bearing on the probability of another).

The research study is based on the following hypotheses:

Hypothesis One: There are no significant statistical indicators of income smoothing practices in Serbian hotel companies during the period 2016-2019.

Hypothesis Two: There are significant statistical indicators of income smoothing practices in Serbian hotel companies during the period 2016-2019.

The hypothesis has been tested using the binomial test. Differences in the groups identified by nonparametric tests in cross-section or as time series indicate that there is a statistically significant difference in performance in the Serbian market between companies that do and do not engage in smoothing. It examines if the observed value differs significantly from the expected value. The calculated frequency value is therefore compared with the previously defined critical value of the binomial distribution. 


\subsection{Sample selection and data}

In this research, secondary data was used which was obtained from Scoring ("Scoring", 2020) and based on the single financial statement's data of 22 hotel companies registered in Serbia from the years 2016 to 2019. This period was chosen because it is the period after mandatory IFRS adoption by Serbian companies. This research study aims to classify Serbian hotel companies during the period 2016-2019 as smoothing and non-smoothing hotel companies. The selection of hotel companies was made randomly according to the availability of financial reports from the website of the Business Registers Agency of the Republic of Serbia. Basically, the size of the hotel company is only divided into three categories: 1 . medium companies, 2 . small companies, and 3. micro-enterprises. The determination of the size of the company is based on the company's total assets. The sample selection does not include large companies.

Meiryani et al. (2020) show that companies controlled by managers tend to do income smoothing compared to those controlled by owners. Small companies will be more likely to practice income smoothing compared to large companies because large companies tend to get more attention from analysts and investors than small companies. Large companies are expected to avoid fluctuations in profits that are too drastic because a drastic increase in profits will cause tax increases. The results of the study Namazi and Khansala (2011) indicated that growth companies achieved a higher degree of income smoothing than value companies. This study suggests that investors should review a company's financial situation before purchasing its stocks, to determine whether it is a value company or a growth company. As the results have revealed, buying stocks from a value company would be riskier than buying from a growth company, although there is more expected profit in the short-term from a value company. Thus, investors must thoroughly consider the balance between a company's potential risks and returns.

In this study, Eckel (1981) model is adopted to measure income smoothing practices. The income smoothing value is calculated using the Eckel index (EI) or Income smoothing (IS) index. In the Eckel index, a company is considered to have taken income smoothing measures if the coefficient of variation from changes in sales is greater than the coefficient of variation from net income changes. These companies (Table 1) were sorted based on the smoothing measures of Eckel (1981) model to give a final sample of 22 Serbian hotel companies during the period 20162019, divided into two groups: 1. smoothers and 2. non-smoothers.

Table 1. List of the analyzed Serbian hotel companies

\begin{tabular}{|l|l|c|}
\hline No. & Name of the hotel company & Size of the hotel company \\
\hline 1. & Hotels Tri O doo Topola & micro \\
\hline 2. & Majdan Luks doo Beograd & small \\
\hline 3. & Hotel Crystal doo Beograd & small \\
\hline 4. & Euro Garni Hotel doo Beograd -Zemun & small \\
\hline 5. & Hotel HTP Plaža doo Beograd & small \\
\hline 6. & Hotel Elegance doo Beograd & small \\
\hline 7. & Hotel Novi Sad doo Novi Sad & small \\
\hline 8. & Hotel Putnik Beograd doo Beograd -Novi Beograd & small \\
\hline 9. & Kopernikus Hotel Prag doo Beograd & small \\
\hline 10. & Hotel Srbija ad Beograd & small \\
\hline 11. & Hotel Zlatibor ad Užice & small \\
\hline 12. & Hotel Mir Zlatibor doo Zlatibor & small \\
\hline 13. & Hotel HTP Olimp Zlatibor & \\
\hline 14. & Hotel HTP Srbija doo Vršac & \\
\hline
\end{tabular}




\begin{tabular}{|l|l|c|}
\hline 15. & Hotel Park ad Novi Sad & medium \\
\hline 16. & Hotels Palisad Zlatibor & medium \\
\hline 17. & Hotel Majestic doo Beograd & medium \\
\hline 18. & Hotel Metropol Palace doo Beograd & medium \\
\hline 19. & Hotel Prezident doo Novi Sad & medium \\
\hline 20. & Slavija Hotels doo Beograd & medium \\
\hline 21. & Hotel Svetlost doo Niš & medium \\
\hline 22. & Todor Hotels doo Beograd & Serbia \\
\hline
\end{tabular}

Source: Business Registers Agency of the Republic of Serbia

\subsection{Empirical results and discussion}

This research study measures the income smoothing activities by using a formula developed by Eckel (1981) the so-called Eckel index. This measure of income smoothing is based on the results gotten from the absolute value in the above model's equation (Formula 1). The income variability approach examines net income and sales for several periods (Thu, \& Khuong, 2017). The income variability method is applied to identify which companies are smoothers and which companies are non-smoothers. The ratio of the coefficient of variation of net income to the coefficient of variation of sales has been used as a proxy for income smoothing. Since sales are less subject to manipulation, the lower degree of the coefficient of variation of net income compared to the coefficient of variation of sales indicates income smoothing. According to the method developed by Eckel, values of the coefficient of variation of the annual change in net income to the coefficient of variation of the annual change in sales which are between -1 and +1 are an indication of smoothing behavior. This is formulated in equation (Ergin, 2011; Thu, \& Khuong, 2017):

$$
\left|C V_{\Delta \mathrm{I}} / C V_{\Delta \mathrm{S}}\right| \leq 1
$$

When:

The variability of net income is lower than the variability of sales, $\left|\mathrm{CV}_{\Delta \mathrm{I}} / \mathrm{CV}_{\Delta \mathrm{S}}\right| \leq 1$ the company is classified as smoother and vice versa.

A company is considered to do income smoothing if the Eckel index is equal to $(=)$ or smaller $(<)$ than one (1) and is considered not to do income smoothing if the Eckel index is greater $(>)$ than one (1) (Obaidat, 2017). If the ratio of the income smoothing (IS) index is equal to $(=)$ or smaller $(<)$ then one (1) between the year $t$ and the year $t-1$ there is the income smoothed and we give to the company an imaginary variable (1). If the ratio of the income smoothing (IS) index is greater $(>)$ than one (1) between the year $t$ and the year $t-1$, the company is classified as non-practice for income smoothing and we give to the company an imaginary variable (0) (Amina, 2018; Firnati, 2019).

The result comprises the statistical analysis of the data, the change in the net income and the change in the sales of the Serbian hotel companies (Table 2). A dummy variable, income smoothing, is given a value of one (1), while no income smoothing is given the value of zero (0).

The numbers (frequency and percentage) of smoother and non-smoother Serbian hotel companies are given in Table 3. 
Table 2. The income smoothing (IS) index and income smoothing (IS) practices in Serbian hotel companies during the period 2016-2019

\begin{tabular}{|c|c|c|c|c|c|c|c|}
\hline \multirow[b]{2}{*}{ No. } & \multirow[b]{2}{*}{ Serbian companies } & \multicolumn{2}{|c|}{ 2016-2017 } & \multicolumn{2}{|c|}{ 2017-2018 } & \multicolumn{2}{|c|}{ 2018-2019 } \\
\hline & & $\begin{array}{c}\text { IS } \\
\text { practices }\end{array}$ & IS index & $\begin{array}{c}\text { IS } \\
\text { practices }\end{array}$ & IS index & \begin{tabular}{c|} 
IS \\
practices
\end{tabular} & IS index \\
\hline 1. & Hotel Crystal doo Beograd & 1 & 0.728 & 1 & 0.209 & 0 & 3.799 \\
\hline 2. & $\begin{array}{l}\text { Euro Garni Hotel doo Beograd } \\
\text {-Zemun }\end{array}$ & 0 & 1.804 & 1 & 0.090 & 0 & 30.102 \\
\hline 3. & Hotel HTP Plaža doo Beograd & 0 & 3.224 & 0 & 6.230 & 0 & 2.698 \\
\hline 4. & Hotel Elegance doo Beograd & 0 & 2.004 & 0 & 7.968 & 0 & 1.853 \\
\hline 5. & Hotel Novi Sad doo Novi Sad & 0 & 9.728 & 0 & 19.464 & 0 & 4.063 \\
\hline 6. & $\begin{array}{l}\text { Hotel Putnik Beograd doo Beograd } \\
\text {-Novi Beograd }\end{array}$ & 1 & 0.006 & 0 & 2.177 & 1 & 0.033 \\
\hline 7. & Hotels Palisad Zlatibor & 0 & 1.409 & 0 & 7.470 & 1 & 0.080 \\
\hline 8. & Hotels Tri O doo Topola & 1 & 0.872 & 1 & 0.190 & 0 & 2.235 \\
\hline 9. & Hotel HTP Olimp Zlatibor & 1 & 0.764 & 0 & 8.601 & 0 & 2.903 \\
\hline 10. & Hotel HTP Srbija doo Vršac & 1 & 0.999 & 0 & 16.967 & 0 & 5.547 \\
\hline 11. & Hotel Park ad Novi Sad & 0 & 6.973 & 0 & 1.107 & 1 & 0.791 \\
\hline 12. & $\begin{array}{l}\text { Kopernikus Hotel Prag doo } \\
\text { Beograd }\end{array}$ & 0 & 9.351 & 0 & 7.456 & 1 & 0.225 \\
\hline 13. & Hotel Majdan Luks doo Beograd & 0 & 10.373 & 0 & 1.938 & 0 & 1.015 \\
\hline 14. & Hotel Majestic doo Beograd & 1 & 0.912 & 0 & 2.269 & 0 & 1.917 \\
\hline 15. & Hotel Metropol Palace doo Beograd & 1 & 0.107 & 0 & 1.378 & 1 & 0.409 \\
\hline 16. & Hotel Prezident doo Novi Sad & 1 & 0.445 & 1 & 0.080 & 1 & 0.183 \\
\hline 17. & Slavija Hotels doo Beograd & 0 & 1.521 & 0 & 1.021 & 0 & 1.413 \\
\hline 18. & Hotel Svetlost doo Niš & 0 & 1.489 & 0 & 2.878 & 0 & 1.061 \\
\hline 19. & Todor Hotels doo Beograd & 1 & 0.476 & 0 & 7.308 & 1 & 0.322 \\
\hline 20. & Hotel Srbija ad Beograd & 0 & 1.661 & 0 & 1.320 & 0 & 104.937 \\
\hline 21. & Hotel Zlatibor ad Užice & 0 & 113.734 & 0 & 3.113 & 0 & 1.204 \\
\hline 22. & Hotel Mir Zlatibor, doo Zlatibor & 0 & 1.299 & 0 & 1.729 & 0 & 1.197 \\
\hline
\end{tabular}

Source: Authors' calculation

Table 3. Results of the income smoothing (IS) classification on Eckel index

\begin{tabular}{|c|c|c|c|c|}
\cline { 2 - 5 } \multicolumn{1}{c|}{} & \multicolumn{2}{c|}{ Smoothed income (1) } & \multicolumn{2}{c|}{ Non-smoothed income (0) } \\
\hline The period & Frequency & Percentage & Frequency & Percentage \\
\hline $\mathbf{2 0 1 6 - 2 0 1 7}$ & 9 & $40.90 \% \approx 41 \%$ & 13 & $59.10 \% \approx 59 \%$ \\
\hline $\mathbf{2 0 1 7 - 2 0 1 8}$ & 4 & $18.18 \% \approx 18 \%$ & 18 & $81.81 \% \approx 82 \%$ \\
\hline $\mathbf{2 0 1 8 - 2 0 1 9}$ & 7 & $31.81 \% \approx 32 \%$ & 15 & $68.19 \% \approx 68 \%$ \\
\hline
\end{tabular}

Source: Authors' calculation

According to the above conditions, the numbers of 22 Serbian hotel companies:

1. in 2016 to 2017 period were selected, in which the number of 9 hotel companies was identified as smoothing and 13 of them as non-smoothing according to Eckel model;

2. in 2017 to 2018 period were selected, in which the number of 4 hotel companies was identified as smoothing and 18 of them as non-smoothing according to Eckel model;

3. in 2018 to 2019 period were selected, in which the number of 7 hotel companies was identified as smoothing and 15 of them as non-smoothing according to Eckel model.

The data analysis consists of descriptive statistics. The descriptive statistics are given in Table 4 . The Mean, Standard deviation, Minimum, Maximum was obtained by SPSS (Statistical Package for Social Sciences) statistical program. 
Table 4. Descriptive statistics for $\left|\mathrm{CV}_{\Delta \mathrm{I}} / \mathrm{CV}_{\Delta \mathrm{S}}\right|$

\begin{tabular}{|c|c|c|c|c|c|}
\cline { 2 - 6 } \multicolumn{1}{c|}{} & $\mathbf{N}$ & Mean & Std. Deviation & Minimum & Maximum \\
\hline VAR00001 & 66 & .3030 & .46309 & .00 & 1.00 \\
\hline VAR00002 & 66 & 6.6489 & 18.99498 & .01 & 113.73 \\
\hline
\end{tabular}

Source: Authors, SPSS output

SPSS produces the following figures when performing the binomial test (Table 5).

Table 5. Calculating the binomial test

\begin{tabular}{|c|c|c|c|c|c|c|}
\cline { 3 - 7 } \multicolumn{2}{c|}{} & Category & N & $\begin{array}{c}\text { Observed } \\
\text { Prop. }\end{array}$ & Test Prop. & $\begin{array}{c}\text { Exact Sig. } \\
\text { (2-tailed) }\end{array}$ \\
\hline \multirow{2}{*}{ VAR00001 } & Group 1 & $<=1$ & 66 & 1.00 & .50 & .000 \\
\cline { 2 - 7 } & Total & & 66 & 1.00 & & .002 \\
\hline \multirow{3}{*}{ VAR00002 } & Group 1 & $<=1$ & 20 & .30 & .50 & .002 \\
\cline { 2 - 7 } & Group 2 & $>1$ & 46 & .70 & & \\
\cline { 2 - 7 } & Total & & 66 & 1.00 & & \\
\hline
\end{tabular}

Source: Authors, SPSS output

The value of sig (a p-value) less than 0.05, indicates that the result is significant (Pallant, 2009). SPSS (Statistical Package for Social Sciences) produces a p-value of 0.002 . This value (the value of sig $=0.002$ ) is less than 0.05 , which indicates that the result is significant. In this study, the critical value is 0.50 . Table 5 shows the percent of the frequencies in the Observed prop. and the expected frequency in the Test prop. The result of the binomial test shows that the sample of Serbian hotel companies practiced income smoothing during the period $2016-2019$ by $30 \%$ with a total of 20 of 66 views, while the percentage of non-practice is $70 \%$ with a total of 46 of 66 views. For the advantages of this test, the value of $\mathrm{Sig}=0.002$ is less than 0.05 . Thus, hypothesis one $\left(\mathrm{H}_{1}\right)$ was rejected and hypothesis two $\left(\mathrm{H}_{2}\right)$ has been accepted, so we can conclude that:

There are significant statistical indicators of income smoothing practices in Serbian hotel companies during the period 2016-2019.

\section{CONCLUSION}

During economic turbulence, companies are under pressure that makes them turn to the accounting department in an attempt to control the frustrations by changing the financial information to their desired level. When the management oversees that the targeted level cannot be managed from the initial planning, they result in decree the figure in earning. This type of management practice to change the accounting records is called income smoothing. When other conditions are identical, the management usually prefers smoothed income over genuine income that fluctuates greatly. Smoothed income allows the firms to evade discounting in the capital market that brings undesirable consequences to the stakeholders. Management of some companies do some conscious manipulating in the financial statement for pretending suitability of profitability items to attract investors. Income is an indicator considered by investors in making investment decisions. The income smoothing practice is a common phenomenon in a company when asymmetric information occurred between managers and shareholders because of the separation of ownership and control. This condition causes managers to have more information about the company than shareholders, and managers often take advantage of the information they have to pursue their interests. As an agent, managers tend to improve the presentation of the financial statements that can be done by income smoothing; so that it looks like to have a good performance in front of the shareholders. 
In this research study, the authors analyze the concept of income smoothing. This study should be of interest to researchers, practitioners, and others concerned with understanding the determinants and usefulness of smoothing. This study aims to determine the existence of practices of income smoothing in hotel companies in Serbia. Based on the study, it can be concluded that companies in the hotel sector in Serbia have empirically conducted income smoothing practices. The study sample consisted of 22 Serbian hotel companies during the period 2016-2019. This study uses the coefficient of variation to measure the variability of net income and sales - Eckel's (1981) method. As a result, if the income smoothing (IS) value is greater ( $>$ ) than one (1), this means that the change in net income is greater than the change in sales; therefore, the company is not an artificial income smoother. If the IS value is equal $(\Rightarrow)$ to smaller $(<)$ than one $(1)$, then the company is considered as an artificial income smoother. Based on the results, hypothesis one (H1) was rejected and hypothesis two (H2) has been accepted: There are significant statistical indicators of income smoothing practices in Serbian hotel companies during the period 2016-2019.

This research study may still contain weaknesses caused by the following limitations: 1 . this study uses only four years of research, preferably for research related to income smoothing; it is better to use longer financial statement data to be more detailed in its analysis, 2. this study uses the Eckel index as a method of classifying samples, whether the sample of companies includes income or non-income grading companies and 3. this study only uses a sample of hotel companies.

\section{FUTURE RESEARCH DIRECTIONS}

In connection with these limitations, the suggestions that can be submitted for further research can add financial report data with a longer period so better research results could be obtained. Furthermore, for the next research we should be able to use a larger sample, not only in the hotel sector but also in other sectors to be able to compare which companies in the sector use earnings management the most often, especially income smoothing between the various sectors. Future studies can also use other sample classification methods, such as the Jones index, and then compare whether there are different results from the Eckel index that is widely used in previous studies.

\section{REFERENCES}

Abdullah Al Baaj, Q., M., Hadi Al-Zabari, S. A., \& Shareef Al Marshedi, A. A. (2018). The impact of income smoothing on tax profit: an applied study to a sample of international companies. Academy of Accounting and Financial Studies Journal, 22(5), 1-11.

Alexandri, M. B., \& Anjani, W. K. (2014). Income smoothing: impact factors, evidence in Indonesia. International Journal of Small Business and Entrepreneurship Research, 3(1), 21-27.

Al Baaj, Q. M. A., Marshedi, A. A. S. Al, \& Al-Zabari, S. A. H. (2018).The impact of income smoothing on tax profit: An applied study to a sample of international companies. Academy of Accounting and Financial Studies Journal, 22(5), 1-11.

Al-Othman, L. (2019). Income smoothing in banks and insurance companies and its impact on earnings per share - evidence from Jordan. Banks and Bank Systems, 14(4), 126-132. https:// doi:10.21511/bbs.14(4).2019.12.

Altaie, B., Hammood, H., \& Talab, H. (2017). Measurement of income smoothing and its effect on accounting conservatism: an empirical study of listed companies in the Iraqi Stock Exchange. International Journal of Economic Perspectives, 11(3), 710-719. 
Amina, F. (2018). Using Eckel model to measure income smoothing practices the case of French companies. International Journal of Economics and Management Engineering, 12(10), 1284-1287.

Baik, B., Sunhwa, Ch., \& Farber, D. B. (2019). Managerial ability and income smoothing. The Accounting Review, 95(4), 1-46. https://ssrn.com/abstract=3469415.

Bora, M. J., \& Saha A. (2015). Investigation on the presence of income smoothing - A study on the companies listed in NSE. Global Journal of Management and Business Research, 15(3), $1-12$.

Ergin, E. (2011). Income smoothing: evidence from Turkey. Kahramanmaraş Sütçü İmam Üniversitesi İktisadi ve İdari Bilimler Fakültesi Dergisi, 1(2), 27-38.

de Almeida, J. E. F., Neto, A. S., Bastianello, R. F., \& Moneque, E., Z. (2012). Effects of income smoothing practices on the conservatism of public companies listed on the BM\&FBOVESPA. Revista Contabilidade \& Finanças, 23(58), 65-75.

Fengju, X., Fard, R. Y., Maher, L. G., \& Akhteghan, N. (2013). The relationship between financial leverage and profitability with an emphasis on income smoothing in Iran's capital market. European Online Journal of Natural and Social Sciences, 2(3), 156-164.

Feres de Almeida, J. E., Neto, A. S., Bastianello, R. F., \& Moneque E. Z. (2012). Effects of income smoothing practices on the conservatism of public companies listed on the BM\&FBOVESPA. Revista Contabilidade \& Finanças, 23(58), 65-75.

Firnanti, F. (2019). The influence of dividend policy and income tax on income smoothing. Accounting and Finance Review, 4(1), 15-20.

Husaini, \& Sayunita (2016). Determinant of income smoothing at manufacturing firms listed on Indonesia Stock Exchange. International Journal of Business and Management Invention, 5(9), 1-4.

Indrawan, V., Pangaribuan, H., Muse, O., Popoola, O. M. J., \& Agoes, S. (2018). The impact of audit committee, firm size, profitability, and leverage on income smoothing. Indian-Pacific Journal of Accounting and Finance, 2(1), 61-74.

Kustonovo, A., S. (2011). The theoretical construction of income smoothing measurement. Journal of Economics, Business, Accountancy Ventura, 14(1), 59-78.

Kusuma, I. W. (2005). Do income smoothing practices explain the lower earnings-price ratio of Japanese firms compared to those of the U.S. firms?. Gadjah Mada International Journal of Business, 7(1), 69-94.

Martinez, A. L., \& Castro, M. A. R. (2011). The smoothing hypothesis, stock returns and risk in Brazil. BAR - Brazilian Administration Review, 8(1), 1-20.

Meiryani, R. A., Puspokusumo, A. W., Udjaja, Y., \& Juwita, A. (2020). The effect of debt to equity and company size on income smoothing practices. Journal of Critical Reviews, 7(7), 316319. https://doi.org/10.31838/jcr.07.07.51

Mushtaq, A., Sultan, H., \& Ijaz, F. (2016). Income smoothing and Islam: evidence from Pakistan Shari 'ah compliant companies. Journal of Islamic thought and civilization, 6(2), 77-93.

Namazi, M., \& Khansalar, E. (2011). An investigation of the income smoothing behavior of growth and value firms (case study: Tehran Stock Exchange market). International Business Research, 4(4), 84-93.

Nejad, H. S., Zeynali, S., \& Alavi, S. S. (2013). Investigation of income smoothing at the companies listed on the stock exchange by the using index Eckel (case study: Tehran Stock Exchange). Asian Journal of Management Sciences and Education, 2(2), 49-62.

Obaidat, A. N. (2017). Income smoothing behavior at the times of political crises. International Journal of Academic Research in Accounting, Finance and Management Sciences, 7(2), 1-13. https:// doi:10.46223/hcmcoujs.econ.en.7.2.188.2017. 
Pallant, J. (2009). SPSS: Priručnik za preživljavanje [SPSS: Guide for survival]. Belgrade: Mikro knjiga.

Savitri, E. (2019). Can effective tax rates mediate the effect of profitability and debts on income smoothing?. Problems and Perspectives in Management, 17(3), 89-100.

Suyono, E. (2018). Institutional ownership, types of industry, and income smoothing: empirical evidence from Indonesia. Journal of Auditing, Finance, and Forensic Accounting, 6(1), 1-12.

Thu, P. A., \& Khuong, N. V. (2017). Investigating income smoothing: empirical evidence from Vietnam's listed companies. Journal of Science Ho Chi Minh City Open University, 7(2), 82-95. http://journalofscience.ou.edu.vn/index.php/econ-en/article/view/188/154.

Tucker, J. W., \& Zarowin P. A. (2006). Does income smoothing improve earnings informativeness?. The Accounting Review, 81(1), 251-270. 